Check for updates

Cite this: RSC Adv., 2017, 7, 47775

\title{
(4-Methoxy)-phenoxy pentafluorocyclotriphosphazene as a novel flame retardant and overcharge protection additive for lithium-ion batteries $\uparrow$
}

\author{
T. Huang, X. Z. Zheng, G. F. Fang, Y. Pan, W. G. Wang and M. X. Wu (DD* \\ We evaluate (4-methoxy)-phenoxy pentafluorocyclotriphosphazene (4-MPPFPP) as a novel flame retardant \\ and overcharge protection additive for lithium-ion batteries. The flammability of electrolytes containing 4- \\ MPPFPP was studied by measuring the self-extinguishing time of the electrolytes. We found that 4-MPPFPP \\ suppresses the flammability of the electrolyte. Moreover, 4-MPPFPP can be electrochemically polymerized \\ on the surface of an electrode. This will protect batteries from voltage runaway. The influence of proper 4- \\ MPPFPP addition on the cycling performance and capacity is negligible. The results may be helpful for the \\ further design of advanced lithium ion battery electrolytes. We discuss the effect of the additive on the \\ electrode/electrolyte interface and propose possible reaction paths.
}

Received 25th August 2017

Accepted 29th September 2017

DOI: 10.1039/c7ra09416g

rsc.li/rsc-advances

protection. $^{20-22}$ These compounds can be electrochemically polymerized on the cathode during overcharging. The resulting polymer film acts as a passivation layer to increase the internal impedance and will eventually shut down the LIB.

If an additive such as resorcinol bis(diphenyl phosphate) $(\mathrm{RDP})^{21}$ or tri-(4-methoxythphenyl) phosphate (TMPP) ${ }^{23}$ can both be a flame retardant and offer overcharge protection, then it would provide more reliable protection. In this paper, (4-methoxy)-phenoxy pentafluorocyclotriphosphazene (4-MPPFPP) was synthesized as a flame retardant and overcharge protection additive in LIB electrolytes. This additive can suppress the ignitability of the electrolyte and polymerize to form a conductive polymer, bypassing the reaction current. The possible reaction paths and the electrochemical compatibility of the electrolyte with the additive are also discussed.

\section{Experimental}

\section{4-MPPFPP synthesis}

The $\mathrm{N}_{3} \mathrm{P}_{3} \mathrm{~F}_{5} \mathrm{OC}_{6} \mathrm{H}_{4} \mathrm{OCH}_{3}$ (4-MPPFPP) was synthesized as shown in Scheme 1. In a $500 \mathrm{ml}$ three-mouth round bottom flask equipped with an electric mixer, a thermometer and a reflux for the overcharge protection of $\mathrm{LiFePO}_{4}$ due to the low redox potential. ${ }^{13-19}$ Additives such as dimethoxydiphenylsilane (DDS), resorcinol bis(diphenyl phosphate) (RDP), and $N$-ethyl-2pyrrolidone (NEP) have also been investigated for overcharge

Key Laboratory of Optoelectronic Materials Chemistry and Physics, Fujian Institute of Research on the Structure of Matter, Chinese Academy of Sciences, Fuzhou 350002, P. R. China.E-mail:mxwu@fjirsm.ac.cn

$\dagger$ Electronic supplementary information (ESI) available. See DOI: 10.1039/c7ra09416g
Scheme 1 Synthetic rou
pentafluorocyclotriphosphazene.

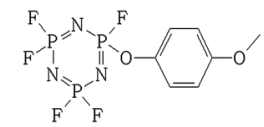

4-MPPFPP 
condenser, $250 \mathrm{ml}$ hexane, $23.8 \mathrm{~g}$ (0.225 mol) sodium carbonate, $50 \mathrm{~g}(0.20 \mathrm{~mol})$ hexafluorocyclotriphosphazene, and $27.5 \mathrm{~g}(0.22$ mol) 4-methoxyphenol were added. These materials were stirred at $60{ }^{\circ} \mathrm{C}$ for 6 hours, and the resulting mixture was allowed to cool to room temperature. The mixture was then poured into $1000 \mathrm{ml}$ cold water, and the organic layer was separated, washed with $10 \%$ (wt) sodium hydroxide aqueous solution and water, dried over anhydrous magnesium sulfate, and filtered. The solvent was distilled under ambient pressure. The product was distilled under vacuum to obtain $56.2 \mathrm{~g}$ (92-94 ${ }^{\circ} \mathrm{C} / 18$ Torr) 4MPPFPP. ${ }^{1} \mathrm{H}-\mathrm{NMR}\left(400 \mathrm{MHz}, \mathrm{CDCl}_{3}, \mathrm{ppm}\right): 7.12$ (d, $J=8.0 \mathrm{~Hz}$, $2 \mathrm{H}), 6.89$ (d, $J=8.0 \mathrm{~Hz}, 2 \mathrm{H}), 3.80(\mathrm{~s}, 3 \mathrm{H}) .{ }^{13} \mathrm{C}-\mathrm{NMR}(400 \mathrm{MHz}$, $\mathrm{CDCl}_{3}, \mathrm{ppm}$ ): 157.95 (d), 142.15 (d), 121.54 (d), 114.99 (d), 55.60. ${ }^{19} \mathrm{~F}-\mathrm{NMR}\left(400 \mathrm{MHz}, \mathrm{CDCl}_{3}, \mathrm{ppm}\right):-65.75$ to $-66.00(\mathrm{~m}),-67.61$ to $-68.47(\mathrm{~m}),-70.17$ to $-70.76(\mathrm{~m}) .{ }^{31} \mathrm{P}-\mathrm{NMR}(400 \mathrm{MHz}$, $\left.\mathrm{CDCl}_{3}, \mathrm{ppm}\right):$ 14.57-16.46 (m), 11.82-13.82 (m), 8.69-10.91 (m), 6.15-8.22 (m), 3.13-5.03 (m). See Fig. S1-S4 in the ESI. $\dagger$

\section{Electrolyte and electrode preparation}

$1 \mathrm{M} \mathrm{LiPF}_{6} / \mathrm{EC}+\mathrm{DMC}+\operatorname{EMC}(1: 1: 1, \mathrm{wt} \%)$ was selected as a base electrolyte. The 4-MPPFPP was added directly to the $1 \mathrm{M}$ $\mathrm{LiPF}_{6} / \mathrm{EC}+\mathrm{DMC}+\mathrm{EMC}$ electrolyte. This was prepared in an argon-filled glove box (the oxygen and water content were less than 5 ppm).

The $\mathrm{LiMn}_{2} \mathrm{O}_{4}$ electrode consisted of $\mathrm{LiMn}_{2} \mathrm{O}_{4}$ (80 wt\%), acetylene black (10 wt\%) and poly(vinylidene fluoride) (PVDF) (10 wt \%). These were made on aluminum. The separators consisted of 2025-type coin cells of $\mathrm{LiMn}_{2} \mathrm{O}_{4} / \mathrm{Li}$ with Celgard 2325 microporous membrane as the separator and were assembled in the glove box. The MCMB/Li cells were fabricated similarly to the $\mathrm{LiMn}_{2} \mathrm{O}_{4} / \mathrm{Li}$ cells and were made on copper.

\section{Characterization}

The procedure for self-extinguishing measurements is to use fiber glass $(-13 \mathrm{~mm}$ in length) soaked in $15 \mathrm{ml}$ of electrolyte for $24 \mathrm{~h}$. The fiber glass was then exposed to a burner for $15 \mathrm{~s}$ to allow ignition and the burning time of the electrolyte was recorded. Each test was repeated four times, and the burning times were averaged.

The conductivity of the electrolyte with and without 4MPPFPP was measured and calibrated with reference to the conductivity of $0.1 \mathrm{M} \mathrm{KCl}$ solution, using a conductivity measuring meter (DDS-307, Shanghai, China).

The overcharge behavior and cycling measurements of the $\mathrm{LiMn}_{2} \mathrm{O}_{4} / \mathrm{Li}$ cells were tested using the LAND cell test system (Land CT 2001A, China). The initial twelve formation cycles were as follows: $0.1 \mathrm{C}\left(1 \mathrm{C}=148 \mathrm{~mA} \mathrm{~g}^{-1}\right)$ three times, $0.2 \mathrm{C}$ three times, 0.5C three times, and $1.0 \mathrm{C}$ three times at $25{ }^{\circ} \mathrm{C}$ under constant current conditions from 3.0-4.3 V. The cells were charged and discharged at $0.5 \mathrm{C}$ between 3.0 and $4.3 \mathrm{~V}$ and then overcharged to $5.0 \mathrm{~V}$ at $1 \mathrm{C}$. To evaluate the influence of 4-MPPFPP on the cycling performance of the $\mathrm{LiMn}_{2} \mathrm{O}_{4} / \mathrm{Li}$ and $\mathrm{MCMB} / \mathrm{Li}$ cells, cycling tests were carried out with a constant current of $1 \mathrm{C}$ from $3.0-4.3 \mathrm{~V}$ at $55^{\circ} \mathrm{C}$. The $\mathrm{MCMB} / \mathrm{Li}$ cells were first cycled at $0.2 \mathrm{C}\left(1 \mathrm{C}=372 \mathrm{~mA} \mathrm{~g}^{-1}\right)$ five times for formation and then at $0.5 \mathrm{C}$ at $25{ }^{\circ} \mathrm{C}$ for the cycling performance test. Rate performances of the $\mathrm{LiMn}_{2} \mathrm{O}_{4} / \mathrm{Li}$ cells were obtained by cycling the cells for three cycles of $0.1 \mathrm{C}, 0.2 \mathrm{C}, 0.5 \mathrm{C}, 1 \mathrm{C}, 2 \mathrm{C}$ and $5 \mathrm{C}$ for charge and discharge, respectively.

The electrochemical impedance spectroscopy of the cells before and after the overcharge test was performed via a frequency response analyzer (VSP, Bio-logic). The frequency range was from $100 \mathrm{kHz}$ to $10 \mathrm{mHz}$, and the amplitude was $5 \mathrm{mV}$.

The morphological changes at the electrodes after overcharging were observed. The electrodes were rinsed with dimethyl carbonate (DMC) three times prior to surface analysis. Field emission scanning electron microscopy (SU-8010, Hitachi) was used to investigate the morphology of the electrodes. The chemical composition of the surface layer on the $\mathrm{LiMn}_{2} \mathrm{O}_{4}$ was analyzed by X-ray photoelectron spectroscopy (ESCALAB 250, Thermo Scientific) with $\mathrm{Al} \mathrm{K} \alpha$ line as an X-ray source. The binding energies were calibrated using containment carbon $(\mathrm{C}$ $1 \mathrm{~s}=284.6 \mathrm{eV})$.

The cells were disassembled in an argon-filled glove box to recover the electrolyte. The electrolytes before/after the overcharge test were characterized by ${ }^{1} \mathrm{H}$ nuclear magnetic resonance spectroscopy (NMR, AVANCE III, Bruker Bopspin) using $\mathrm{CD}_{3} \mathrm{CN}$ as a solvent.

\section{Results and discussion}

\section{Flammability and conductivity}

In this study, the self-extinguishing time (SET) was used to evaluate the flammability of the electrolytes. Fig. 1(a) shows the results of the SET tests for solutions containing different concentrations of 4-MPPFPP in the electrolyte. The burning time of the electrolyte decreases with increasing 4-MPPFPP concentration. The SET value of the base electrolyte is $\mathbf{1 5 . 0 8}$ $\mathrm{s} \mathrm{cm}{ }^{-1}$, and only $10.7 \mathrm{~s} \mathrm{~cm}^{-1}$ for the electrolyte containing 8 vol\% 4-MPPFPP. Although the SET value of the electrolyte containing 5 vol\% 4-MPPFPP is $13.7 \mathrm{~s} \mathrm{~cm}^{-1}$, the flame propagation time increases from $0.62 \mathrm{~s} \mathrm{~cm}^{-1}$ to $9.23 \mathrm{~s} \mathrm{~cm}^{-1}$ (Fig. 1(b)). The flammability of the electrolytes with and without the 4MPPFPP additive can be visualized in Fig. 2. Obviously, for the base electrolyte the fire spreads very quickly, while the electrolyte with 5 vol\% 4-MPPFPP additive postpones the spread of fire under these testing conditions. The flame-retardant performance of 4-MPPFPP is attributed to the introduction of $\mathrm{F}, \mathrm{N}$, and $\mathrm{P}$, and due to the radical adsorption and oxygen isolation mechanism. ${ }^{24}$ Additionally, the influence of 4-MPPFPP on the conductivity was also evaluated as shown in Fig. 1(c). The conductivity of the electrolyte decreases as the concentration of the additive increased due to its high viscosity and low dielectric constant.

\section{Overcharge behavior of 4-MPPFPP in the $\operatorname{LiMn}_{2} \mathrm{O}_{4} / \mathrm{Li}$ cells}

Fig. 3(a) compares the $\mathrm{LiMn}_{2} \mathrm{O}_{4} / \mathrm{Li}$ cells during charging using the electrolyte without an additive, with 5 vol\% 4-MPPFPP, and with 5 vol\% PFPN. All of the cells were charged to $4.3 \mathrm{~V}$ at $0.5 \mathrm{C}$, and then overcharged to $5.0 \mathrm{~V}$ at $1 \mathrm{C}$. There is not much difference between these cells during normal charging. However, the 
(a)

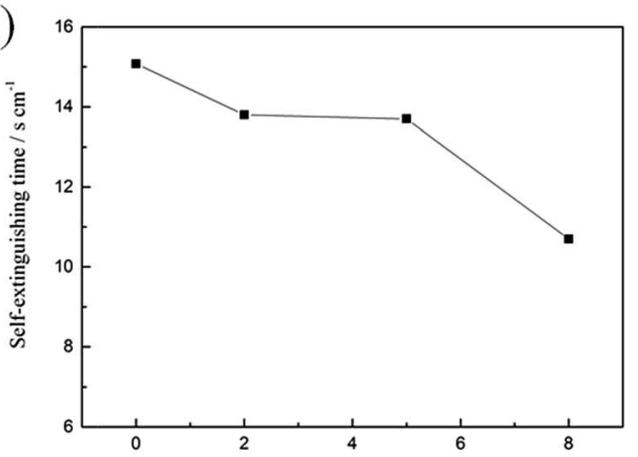

(b)

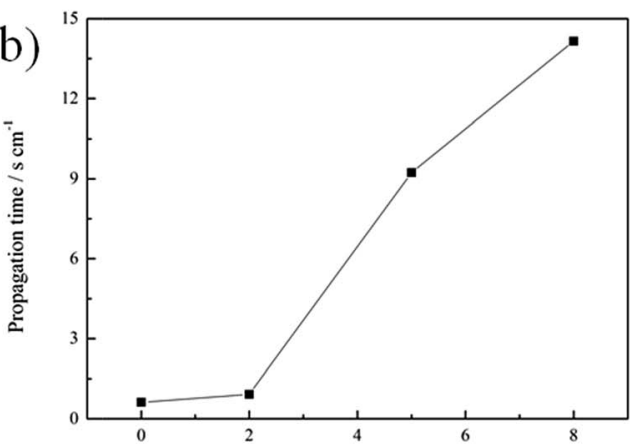

(c)

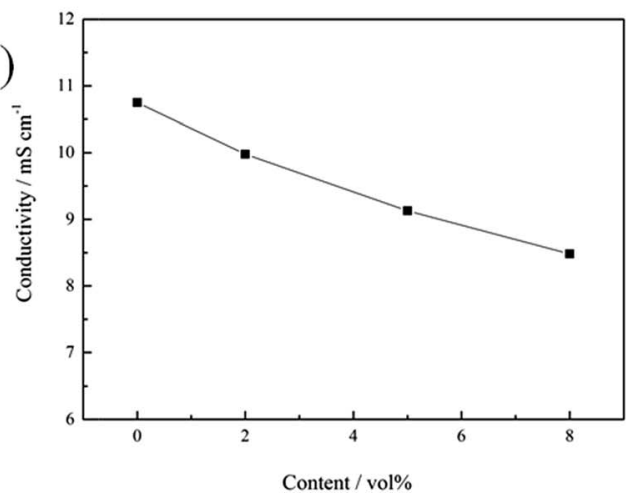

Fig. 1 The self-extinguishing time (a), flame propagation time (b) and conductivity (c) of the electrolytes containing different concentrations of 4-MPPFPP.

voltage at the overcharged stage rises up sharply to $5 \mathrm{~V}$ for the cells without an additive and with 5 vol\% PFPN, while a charging voltage plateau of $4.45-5.0 \mathrm{~V}$ was observed for the cell with 4-MPPFPP. This suggests that the incorporation of $5 \mathrm{vol} \%$ 4-MPPFPP can dramatically postpone the growth of potential during the overcharge process. At the same time, we believe that the structures of A and C can't protect the $\mathrm{LiMn}_{2} \mathrm{O}_{4} / \mathrm{Li}$ cells from voltage runaway at overcharge.

Fig. 3(b) shows the difference in the differential capacity plots of $\mathrm{LiMn}_{2} \mathrm{O}_{4} / \mathrm{Li}$ cells with and without an additive. We find there are two oxidation peaks with the first sharp peak around $4.45 \mathrm{~V}$ and the second broad peak ranging from 4.6 to $5 \mathrm{~V}$ due to the addition of 4-MPPFPP. It is known that most anisoles act as redox shuttle agents. ${ }^{25,26}$ So, we believe that the first sharp peak is due to the oxidation of 4-MPPFPP as a redox shuttle reaction

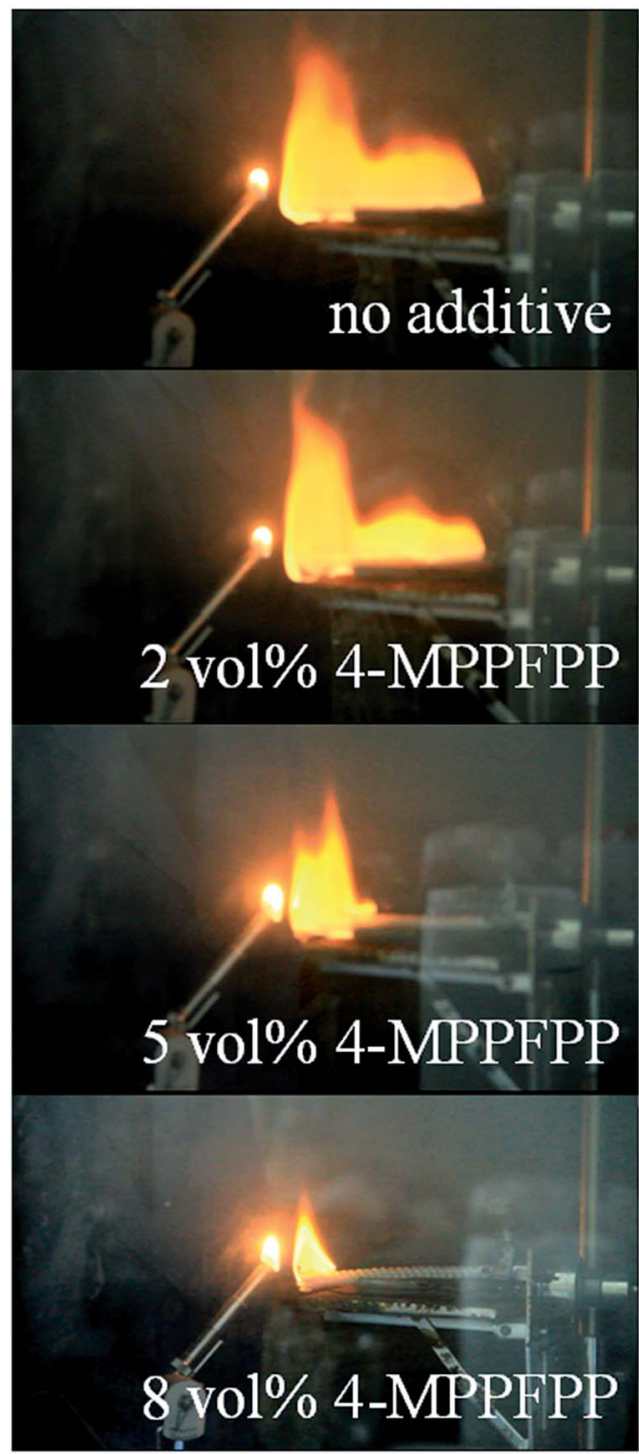

Fig. 2 The flammability of the electrolytes with and without 4MPPFPP.

and the second broad peak may originate from the decomposition of 4-MPPFPP to achieve electrochemical polymerization.

Fig. 4 presents the results of the $\mathrm{LiMn}_{2} \mathrm{O}_{4} / \mathrm{Li}$ cells with and without 5 vol\% 4-MPPFPP. The typical EIS of the Li-ion cells is composed of two partially overlapped semicircles and a straight slopping line at the low frequency end. ${ }^{27} R_{\mathrm{f}}$ is attributed to the solid-state interphase layer (SEI) formed on the surface of the electrodes, and $R_{\mathrm{ct}}$ is the faradic charge-transfer resistance. Before overcharge, the impedances are similar for both electrodes with and without 4-MPPFPP. The $\mathrm{LiMn}_{2} \mathrm{O}_{4} / \mathrm{Li}$ cell without an additive showed an interfacial impedance of about $18.76 \Omega$ and a charge-transfer impedance of about $26.36 \Omega$. In contrast, the cell with 5 vol\% 4-MPPFPP showed an interfacial impedance of about $17.94 \Omega$ and a charge-transfer impedance of about $25.26 \Omega$. For the cell with 4-MPPFPP, the interfacial resistance after overcharge $(94.76 \Omega)$ is slightly bigger than that of the cell without the additive (24.49 $\Omega$ ) indicating a thick interface 


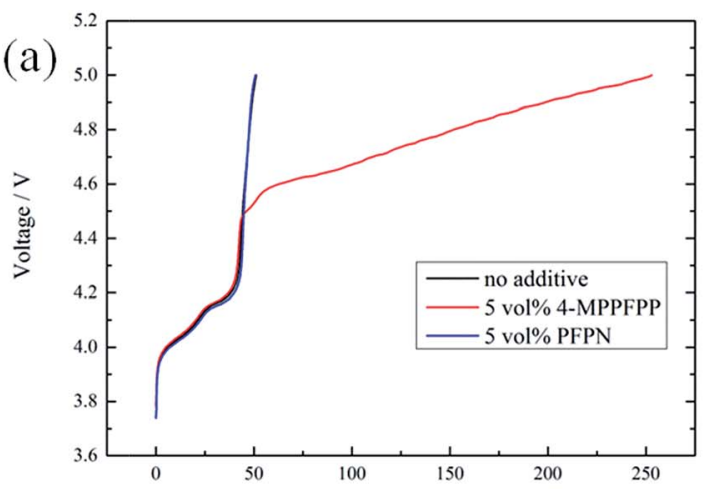

Time $/ \mathrm{min}$

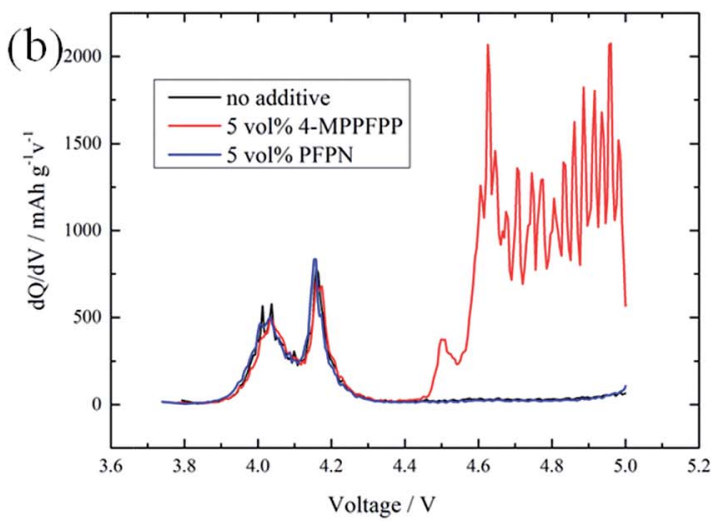

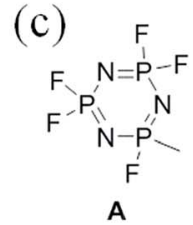

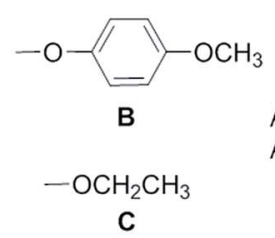

AB:4-MPPFPP $A C: P F P N$

Fig. $3 \quad V-t$ profiles (a) and the differential capacity plots (b) of $\mathrm{LiMn}_{2} \mathrm{O}_{4} / \mathrm{Li}$ cells with the electrolyte without an additive, with 5 vol\% 4-MPPFPP, and with 5 vol\% PFPN. The structures of 4-MPPFPP and PFPN (c)
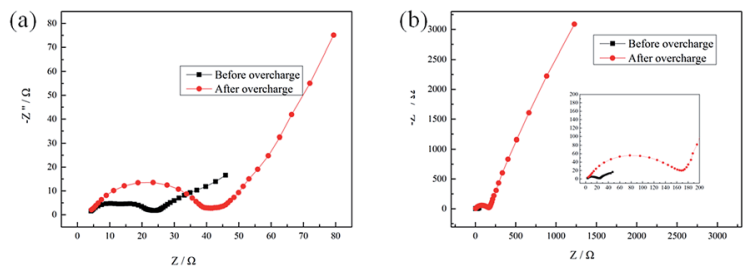

Fig. 4 Electrochemical impedance spectra of $\mathrm{LiMn}_{2} \mathrm{O}_{4} / \mathrm{Li}$ cells (a) without and (b) with 5 vol\% 4-MPPFPP before and after the overcharge test

between the electrode and the electrolyte. The charge transfer resistance rises up to about $118.7 \Omega$, which is higher than the value of the cell without the additive $(37.08 \Omega)$. The sharp increase in the charge transfer resistance may be due to the thick film formed on the cathode by 4-MPPFPP, which is nonconductive and inhibits the charge transfer process.
The cells were disassembled in a glove box under Ar atmosphere to analyze the effect of 4-MPPFPP on the $\mathrm{LiMn}_{2} \mathrm{O}_{4}$ surface after overcharge. SEM images show that the electrode exhibits a porous structure (Fig. 5(a)). No distinct surface layer was observed. The bulk structure of primary particles of the $\mathrm{LiMn}_{2} \mathrm{O}_{4}$ electrode was maintained well after the overcharge test (Fig. 5(c)). However, after being overcharged to $5 \mathrm{~V}$ in the electrolyte with 5 vol\% 4-MPPFPP, the electrode surface was fully covered with a thick film (Fig. 5(b)). The particle edge of the electrode with the additive electrolyte becomes indistinct (Fig. 5(d)).

The surfaces of the $\mathrm{LiMn}_{2} \mathrm{O}_{4}$ electrodes after being overcharged with different electrolytes were analyzed by XPS. The $\mathrm{Mn} 2 \mathrm{p}, \mathrm{O} 1 \mathrm{~s}$, and $\mathrm{N}$ 1s spectra of the $\mathrm{LiMn}_{2} \mathrm{O}_{4}$ electrodes are shown in Fig. 6. In the Mn $2 \mathrm{p}$ spectra, there are main peaks dominated by Mn $2 \mathrm{p}_{3 / 2}$ (642.9 eV (ref. 28) and $641.7 \mathrm{eV}$ (ref. 28)) and $\mathrm{Mn} 2 \mathrm{p}_{1 / 2}$ (653.6 eV (ref. 28)). The intensity of the peaks for the surface of the $\operatorname{LiMn}_{2} \mathrm{O}_{4}$ electrode without the additive is much stronger than that with the additive. In the $\mathrm{O} 1 \mathrm{~s}$ spectra, the intensity of the Mn-O peak (529.6 eV (ref. 29)) observed on the surface of the $\mathrm{LiMn}_{2} \mathrm{O}_{4}$ electrode without the additive is stronger than that with 5 vol\% 4-MPPFPP. This is due to a thick film which comes from the 4-MPPFPP on the electrode surface. In the $\mathrm{N} 1 \mathrm{~s}$ spectra, the surface of the $\mathrm{LiMn}_{2} \mathrm{O}_{4}$ is covered with some nitrogen compounds. Based on the XPS results, we have assumed that the 4-MPPFPP additive helps form the thick film.

Fig. 7 shows the ${ }^{1} \mathrm{H}$ NMR data for the electrolytes with 5 vol\% 4-MPPFPP before/after the overcharge test. We can find that there are two groups of chemical shifts attributed to 4-MPPFPP in Fig. 7. One is located at $7.12 \mathrm{ppm}\left(\mathrm{H}_{\mathrm{A}}\right)$ and has two splitting peaks. The other is located at $6.89 \mathrm{ppm}\left(\mathrm{H}_{\mathrm{B}}\right)$ and also has two splitting peaks. The intensities of the $7.12 \mathrm{ppm}$ and $6.89 \mathrm{ppm}$ peaks are smaller after being overcharged, as shown in Fig. 7(b), and the ratio was approximately $1: 1$. For redox additives, the additive concentration should be maintained after the cell is overcharged. We assume that this decomposition reaction could be strongly related to the polymerization reaction of 4MPPFPP. The possible reaction paths are presented in Fig. $8 .{ }^{30,31}$

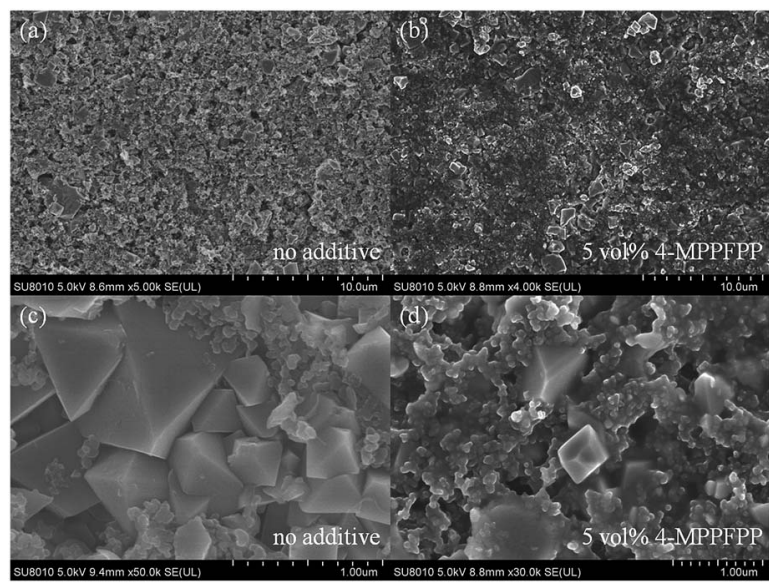

Fig. 5 SEM images of the $\mathrm{LiMn}_{2} \mathrm{O}_{4}$ electrode taken from the overcharged cells ( $a$ and $c$ ) without and ( $b$ and $d$ ) with 5 vol\% 4-MPPFPP electrolyte. 

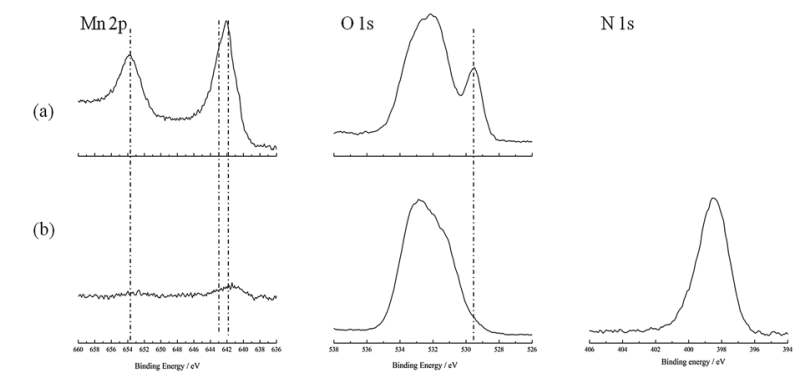

Fig. 6 The $\mathrm{Mn} 2 \mathrm{p}, \mathrm{O} 1 \mathrm{~s}$, and $\mathrm{N}$ 1s spectra of the $\mathrm{LiMn}_{2} \mathrm{O}_{4}$ electrodes taken from the overcharged cells without (a) and with (b) 5 vol\% 4MPPFPP.
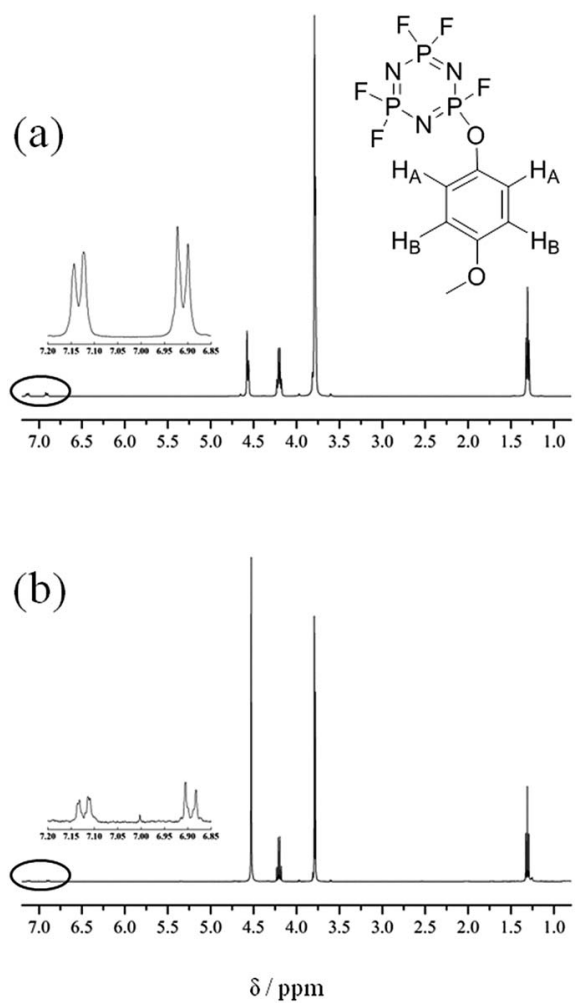

Fig. $7{ }^{1} \mathrm{H}$ NMR data for the electrolyte with 5 vol\% 4-MPPFPP before overcharge (a) and the electrolyte taken from the cell with 5 vol\% 4MPPFPP after the overcharge test (b).

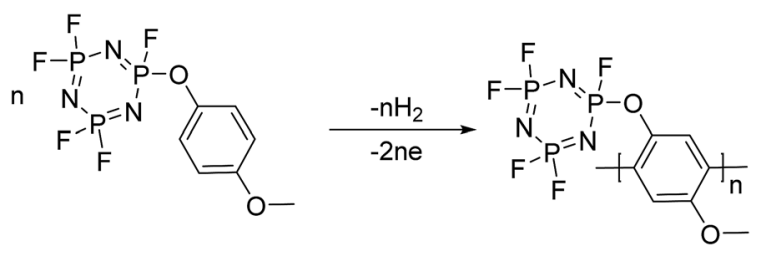

Fig. 8 The possible reaction paths of 4-MPPFPP on the cathode.

\section{Cycling performance of 4-MPPFPP in the $\mathrm{LiMn}_{2} \mathrm{O}_{4} / \mathrm{Li}$ and MCMB/Li cells}

To evaluate the influence of 4-MPPFPP on the electrochemical performance of the $\mathrm{LiMn}_{2} \mathrm{O}_{4} / \mathrm{Li}$ cells and $\mathrm{MCMB} / \mathrm{Li}$ cells, cycling
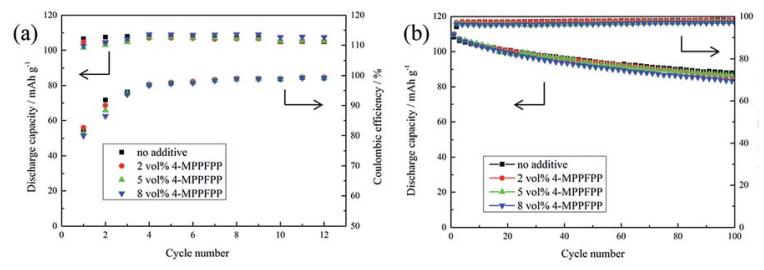

Fig. 9 Formation cycles of the $\mathrm{LiMn}_{2} \mathrm{O}_{4} / \mathrm{Li}$ cells at $25^{\circ} \mathrm{C}$ (a) and the cycling performance of the $\mathrm{LiMn}_{2} \mathrm{O}_{4} / \mathrm{Li}$ cells at $55^{\circ} \mathrm{C}$ (b).
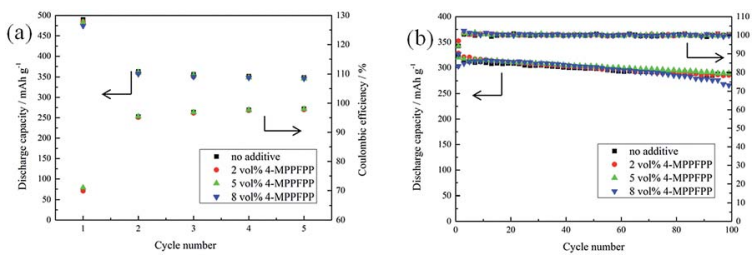

Fig. 10 Formation cycles of the MCMB/Li cells at $25^{\circ} \mathrm{C}(\mathrm{a})$ and the cycling performance of the MCMB/Li cells at $25^{\circ} \mathrm{C}$ (b).

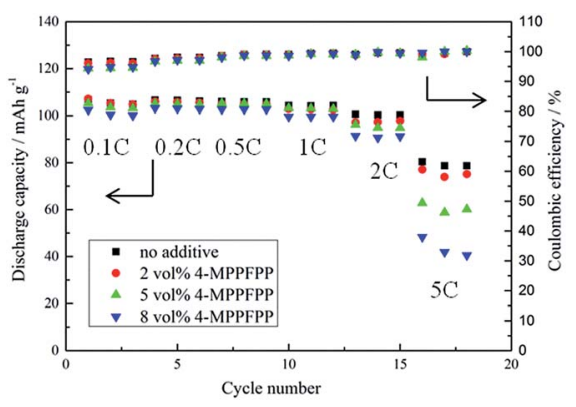

Fig. 11 Rate performance of the $\mathrm{LiMn}_{2} \mathrm{O}_{4} / \mathrm{Li}$ cells at $25^{\circ} \mathrm{C}$.

tests were carried out. Fig. 9(a) shows that the discharge capacity and coulombic efficiency of the cells exhibited no obvious differences during the formation cycles. In Fig. 9(b), it can be found that the $\mathrm{LiMn}_{2} \mathrm{O}_{4} / \mathrm{Li}$ cell without 4-MPPFPP keeps $81.2 \%$ of its initial discharge capacity (after 100 cycles at $55^{\circ} \mathrm{C}$ ), while the $\mathrm{LiMn}_{2} \mathrm{O}_{4} / \mathrm{Li}$ cell with $5 \mathrm{vol} \%$ 4-MPPFPP keeps $79.2 \%$ (after 100 cycles at $55{ }^{\circ} \mathrm{C}$ ). The $\mathrm{LiMn}_{2} \mathrm{O}_{4} / \mathrm{Li}$ cell with $8 \mathrm{vol} \% 4^{4}$ MPPFPP retains $76.1 \%$ of its initial discharge capacity after 100 cycles at $55{ }^{\circ} \mathrm{C}$. This indicates that a higher ratio of 4-MPPFPP might cause a lower cycling capability and coulombic efficiency. The capacity only slightly decreases due probably to the dilution of $\mathrm{LiPF}_{6}$ concentrations and trace impurities.

Fig. 10 shows the formation cycles and cycling performance of the MCMB/Li cells at $25{ }^{\circ} \mathrm{C}$ with different electrolytes. These results confirm that $5 \mathrm{vol} \%$ 4-MPPFPP has no negative effect on the $\mathrm{MCMB} / \mathrm{Li}$ cells.

Fig. 11 presents the rate performance of the $\mathrm{LiMn}_{2} \mathrm{O}_{4} / \mathrm{Li}$ cells at $25{ }^{\circ} \mathrm{C}$. The cells with the 4-MPPFPP electrolyte additive generally exhibited only slightly lower discharge capacities than that of the electrolyte without the additive at lower charge/ discharge rates. 


\section{Conclusions}

In summary, 4-MPPFPP was synthesized as a bifunctional additive for a carbonate-based electrolyte for lithium ion batteries. The addition of 4-MPPFPP can shorten the flame extinguishing time of the electrolyte. Besides, 4-MPPFPP can also be polymerized to form a thick polymer film, which can protect the batteries from voltage runaway at overcharge. The influence of 5 vol\% 4-MPPFPP on the cycling performance and capacity is negligible.

\section{Conflicts of interest}

There are no conflicts to declare.

\section{Acknowledgements}

This work was supported by the National Key Research and Development Program of China (Grant No. 2016YFB0100100), the "Strategic Priority Research Program" of the Chinese Academy of Sciences (Grant No. XDA09010103) and the Science and Technology Planning Project of Fujian Province (Grant No. 2017H2045, 2016T3012).

\section{Notes and references}

1 J. K. Feng, X. J. Sun, X. P. Ai, Y. L. Cao and H. X. Yang, J. Power Sources, 2008, 184, 570.

2 H. F. Xiang, H. Y. Xu, Z. Z. Wang and C. H. Chen, J. Power Sources, 2007, 173, 562.

3 D. Zhou, W. Li, C. Tan, X. Zuo and Y. Huang, J. Power Sources, 2008, 184, 589.

4 Z. Zeng, X. Jiang, B. Wu, L. Xiao, X. Ai, H. Yang and Y. Cao, Electrochim. Acta, 2014, 129, 300.

5 X. Zhu, X. Jiang, X. Ai, H. Yang and Y. Cao, Electrochim. Acta, 2015, 165, 67.

6 T. H. Nam, E. G. Shim, J. G. Kim, H. S. Kim and S. I. Moon, J. Power Sources, 2008, 180, 561.

7 L. Xia, Y. Xia and Z. Liu, J. Power Sources, 2015, 278, 190.

8 J. Ara, J. Electrochem. Soc., 2003, 150, A219-A228.

9 K. Naoi, E. Iwama, Y. Honda and F. Shimodate, $J$. Electrochem. Soc., 2010, 157, A190.

10 D. H. C. Wong, J. L. Thelen, Y. F. D. Devaux, A. A. Pandya, V. S. Battaglia, N. P. Balsara and J. M. DeSimone, Proc. Natl. Acad. Sci. U. S. A., 2014, 111, 3327.
11 S. Chen, Z. Wang, H. Zhao, H. i. Qiao, H. Luan and L. Chen, J. Power Sources, 2009, 187, 229.

12 J. A. Choi, Y. K. Sun, E. G. Shim, B. Scrosati and D. W. Kim, Electrochim. Acta, 2011, 56, 10179.

13 L. Lombardo, S. Brutti, M. A. Navarra, S. Panero and P. Reale, J. Power Sources, 2013, 227, 8.

14 Z. Zhang, L. Zhang, J. A. Schlueter, P. C. Redfern, L. Curtiss and K. Amine, J. Power Sources, 2010, 195, 4957.

15 J. Huang, I. A. Shkrob, P. I. Wang, L. Cheng, B. Pan, M. He, C. Liao, Z. Zhang, L. A. Curtiss and L. Zhang, J. Mater. Chem. A, 2015, 3, 7332 .

16 A. P. Kaur, C. F. Elliott, S. Ergun and S. A. Odom, J. Electrochem. Soc., 2016, 163, A1.

17 W. Weng, Z. Zhang, P. C. Redfern, L. A. Curtiss and K. Amine, J. Power Sources, 2011, 196, 1530.

18 B. Wang, Q. Xia, P. Zhang, G. C. Li, Y. P. Wu, H. J. Luo, S. Y. Zhao and T. van Ree, Electrochem. Commun., 2008, 10, 727.

19 A. P. Kaur, S. Ergun, C. F. Elliott and S. A. Odom, J. Mater. Chem. A, 2014, 2, 18190.

20 L. Chen, M. Xu, B. Li, L. Xing, Y. Wang and W. Li, J. Power Sources, 2013, 244, 499.

21 J. Feng and L. Lu, J. Power Sources, 2013, 243, 29.

22 U. Vogl, A. Schmitz, C. Stock, J. P. Badillo, H. J. Gores and M. Winter, J. Electrochem. Soc., 2014, 161, A1407.

23 J. K. Feng, Y. L. Cao, X. P. Ai and H. X. Yang, Electrochim. Acta, 2008, 53, 8265.

24 K. Xu, Nonaqueous, Chem. Rev., 2004, 104, 4303.

25 M. Adachi, K. Tanaka and K. Seika, J. Electrochem. Soc., 1999, 146, 1256.

26 Y. Lee and J. Cho, Electrochim. Acta, 2007, 52, 7404.

27 T. Huang, X. Zheng, Y. Pan, W. Wang, G. Fang and M. Wu, Electrochim. Acta, 2015, 156, 328.

28 N. Treuil, C. Labrugere, M. Menetrier, J. Portier, G. Gampet, A. Deshayes, J. C. Frison, S. J. Hwang, S. W. Song and J. H. Choy, J. Phys. Chem. B, 1999, 103(12), 2100.

29 X. Zuo, C. Fan, X. Xiao, J. Liu and J. Nan, J. Power Sources, 2012, 219, 94.

30 K. Shima, K. Shizuka, M. Ue, H. Ota, T. Hatozaki and J. I. Yamaki, J. Power Sources, 2006, 161, 1264.

31 M. C. Martinez, O. P. Marquez, J. Marquez, F. Hahn, B. Beden, P. Crouigneau, A. Rakotondrainibe and C. Lamy, Synth. Met., 1997, 88(3), 187. 